Research.

\title{
ANALYSIS USE OF FIXED ASSETS DEPRECIATION METHOD ON COMPANY PROFITS
}

\author{
Rina Indrayani \\ Sekolah Tinggi Teknologi Bandung, Indonesia
}

Received: February 08, 2018; Accepted: April 24, 2018; Published: June 30, 2018

To cite this article: Rina Indrayani, Analysis Use of Fixed Assets Depreciation Method on Company Profits, The Accounting Journal of BINANIAGA, Vol. 03, No. 01, June 2018, pp. 59 - 66.

\begin{abstract}
This study was conducted with the aim to know the accounting policy of depreciation of fixed assets determined by the company and how the influence of accounting policy depreciation of fixed assets applied by the company to the company's earnings. The research method used is descriptive method of analysis is a research that aims to collect data that have a relationship with the problems studied, then processed and analyzed and then the solution. While the data used is quantitative data in the form of numbers. After examining and analyzing the company's treatment in calculating depreciation for fixed assets, it can be concluded that the accounting policy of depreciation of fixed assets applied by the company has been in accordance with the applicable financial accounting standards that is straight-line method and the use of different methods will result in different amounts of depreciation. Using the straight-line method of depreciation expense for each fixed period, profits generated in the early years are greater than in subsequent years. While in the method of balance decreased multiply depreciation expense higher in the early years and lower load in the coming period. The resulting profits were smaller in the early years and were greater in previous years.
\end{abstract}

Keywords: depreciation, profit, fixed assets.

\section{INTRODUCTION}

Fixed assets are a very important element, used in the normal operation of the company. The asset still requires a considerable amount of funds in its investment, therefore it takes careful planning in the procurement of fixed assets. The treatment of fixed assets, when at ownership, fixed assets should be recorded and reported at cost. As for the periods after ownership and is used in the normal operation of the enterprise, the fixed assets are recorded and reported at cost less minus depreciation or depreciation accumulated or in the amount of the book value.

The accounting practices of fixed assets and their depreciation have an impact on the financial statements. This is evident from the amount of depreciation depicted in the financial statements. If the value of depreciation is relatively large then this will have an impact on the value of a small profit. If the profit generated is small, the dividend will be received by the small shareholder. Likewise, the tax to be paid by the government is also small. The effect on the balance sheet, the large depreciation expense from period to period resulted in the accumulation will appear large too. Since the accumulation will reduce the book value, the book value shown is also small, so the value on the balance sheet for the fixed asset item cannot provide reliable financial information to the interested parties.

Rina Indrayani:

Analysis Use of Fixed Assets Depreciation Method on Company Profits 


\section{LITERATURE REVIEW}

Fixed Assets are assets acquired in ready-to-use or pre-built form, used in company operations, not intended for sale in the framework of the normal activities of the enterprise and have a useful life of more than one year.

Since fixed assets have a useful life of more than one year, the estimated useful life of those assets should be estimated at the time of acquisition. At the time of acquisition of money to obtain assets is the cost of assets that provide usefulness over the useful life of the fixed assets. Consequently, because the cost of fixed assets is for all benefits, while every year there is always measurement and reporting on the performance of the company that includes income and expenses, the cost of the fixed assets should also be allocated as an expense which later this burden will be compared with the income earned in the current year.

The classification of fixed assets ie, fixed intangible assets and fixed intangible assets. Tangible fixed assets are assets perceived by the human senses consisting of assets in the form of factories and equipment, namely land, buildings, machinery, equipment, furniture, vehicles and auxiliary equipment. While the fixed assets in the form of natural sources include mining, oil content, various mines, gas content, lead content and content in other soils.

Intangible fixed assets include goodwill, trademark, patent, copyright, franchise, establishment of the organization.

At the time of acquisition of tangible fixed assets should be recorded and reported as acquisition cost. While the periods after the ownership and are used in the normal operation of the company, tangible fixed assets should be reduced accumulated depreciation. The acquisition cost is the costs incurred to acquire the fixed assets until the fixed assets are ready for use.

Acquisitions of fixed assets include cash, credit, exchanged for securities, prizes, and self-made.

Expenditures after the acquisition of fixed assets include maintenance, reparations, additions and rearrangements.

Depreciation or depreciation is a systematic loss of value caused by usage, obsolescence, physical deterioration, and inaccuracy, the passage of a time or a change in cost to the burden of a fixed intangible asset.

Total depreciation represents a credit balance called accumulated depreciation which indicates that depreciation is not a process of reserve but a process of acquisition of fixed assets.

Factors in determining depreciation charges:

1. Acquisition price is the price at the time of purchase and all costs to be borne by the company.

2. Age of economics is the age of the fixed assets since ready to be used until the fixed assets are economically no longer profitable if still used.

3. Residual value is the estimated amount to be received when the asset is sold or withdrawn from use.

Depreciation calculation method:

1. Based on time

a. Straight-line method

b. Loading method decreases

(1). Method of number of years

(2). Declining balance method

2. Based on usage

a. Hour service method

b. Number of units of production method

Rina Indrayani:

Analysis Use of Fixed Assets Depreciation Method on Company Profits 


\section{c. Based on other criteria}

3. Based other criteria

a. Type and group method

b. Annuity method

c. Inventory system

\section{RESEARCH METHODOLOGY}

The methodology used in this research is descriptive analysis method is a research that aims to collect data that have relationship with the problems studied, then processed and analyzed and compared with theoretical knowledge to formulate the problem and then solving it.

\section{RESULTS AND DISCUSSION}

The company sets out two policies: cash purchases and credit purchases. Fixed assets acquired through cash purchases will be recorded at their disbursements, if any existing purchase deduction will be included as a deduction of the cost. Purchase on credit is done if the price of fixed assets is relatively large amount.

Table 1

Depreciation of Straight Line and Double Declining Balance Year 2014 - 2017

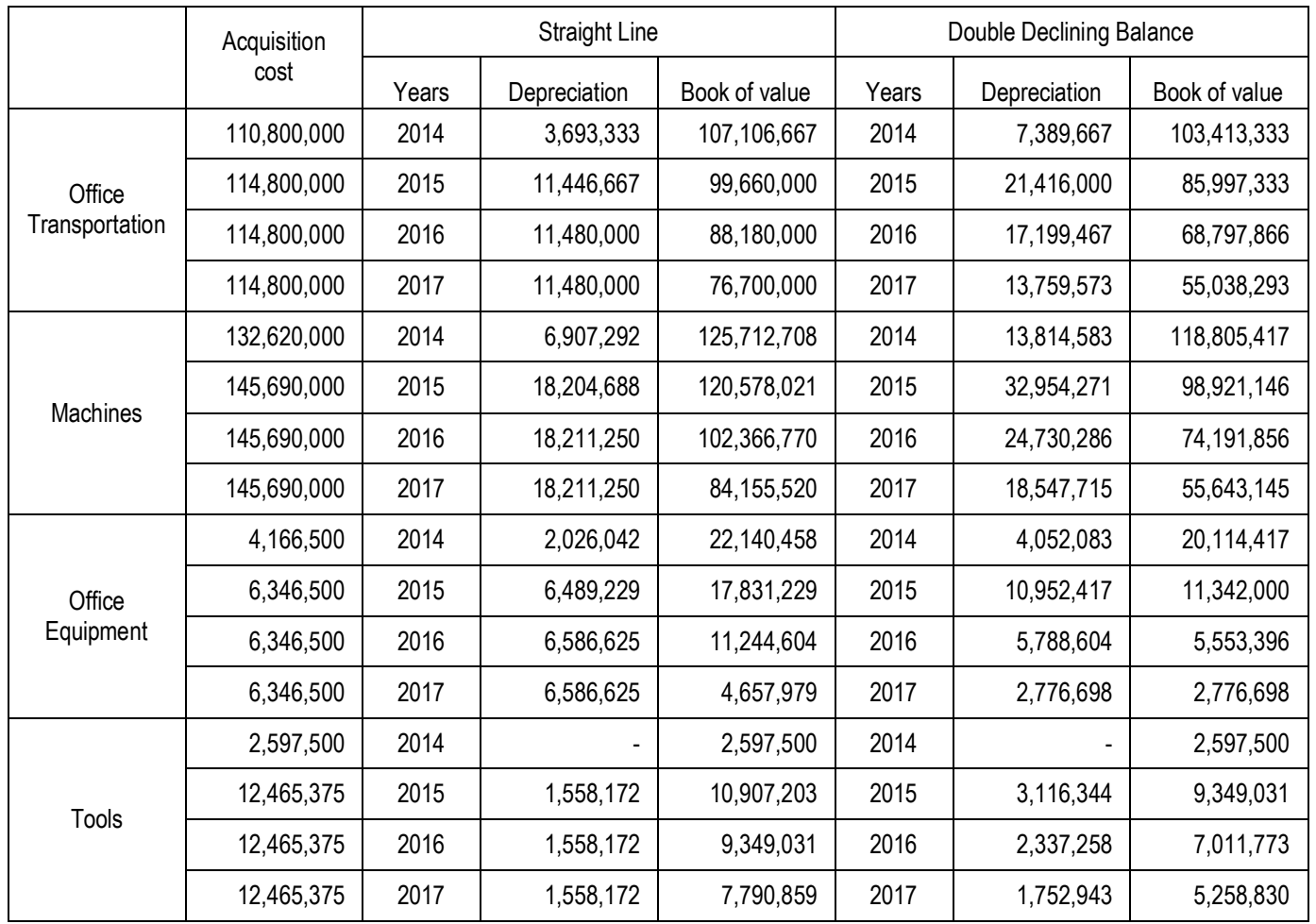

Rina Indrayani:

Analysis Use of Fixed Assets Depreciation Method on Company Profits 
The method used is the straight-line method with the following rates:

\begin{tabular}{|c|c|c|}
\hline Fixed Assets & Age of economi & Rate of depreciation \\
\hline Office Transportation & 10 years & $10 \%$ \\
\hline Office equipment & 4 years & $25 \%$ \\
\hline Machines & 8 years & $12.5 \%$ \\
\hline Tools & 8 years & 12.55 \\
\hline
\end{tabular}

In this research the authors will compare between the methods used are straight line with the method of double declining balance.

Based on the above table it can be seen how much the percentage difference between the straight-line method and the declining-balance method. The type of fixed assets used as a calculation example is a tool with the percentage of comparison shown in the table below

Table 2.

Percentage difference

The straight-line method and the declining-balance method are multiple $2014-2017$

\begin{tabular}{|c|r|r|c|}
\hline Years & Straight Method & \multicolumn{1}{|c|}{$\begin{array}{c}\text { Declining } \\
\text { Balance }\end{array}$} & Percentage \\
\hline 2014 & 0 & 0 & 0 \\
\hline 2015 & 1.558 .172 & 3.116 .344 & $100 \%$ \\
\hline 2016 & 1.558 .172 & 2.337 .258 & $50 \%$ \\
\hline 2017 & 1.558 .172 & 1.752 .943 & $12.5 \%$ \\
\hline
\end{tabular}

Based on the above calculation can be seen the difference in percentage between the straight-line method and the method of declining balances doubled from year to year declining. In the early years of depreciation that is in 2015 there is a difference in the cost of shrinkage between the two methods is $100 \%$. In the following year it was relatively lower than in the previous year but the method of balance decreasing is still $50 \%$ larger than the straight-line method. In 2016 the difference in percentage of small trays is $12.5 \%$.

When using the straight-line method, the depreciation expense of time-to-time is of equal magnitude, since the asset (capacity) usage of each period is relatively fixed and the economic usefulness diminishes over time, while using the method of doubledeclining balance, the depreciation expense in the early years is higher and depreciation expense in the coming period is lower. Because in the early years the assets experienced a greater loss of service in those years and lower depreciation expense in the last period, at which time the cost of reparation and maintenance was often higher.

The company's profit and loss at the beginning of the period based on the straightline method is greater than the doubled declining balance of profit, but profit in the following period is greater than the straight-line method. One of the reasons for this difference is from the recognition of the depreciation cost, for the straight-line method the depreciation cost is likely to remain so that the effect on earnings is very small. As for the method of declining balance depreciation costs tend to decrease, so the profit generated tends to increase. On the double declining depreciation at the beginning of its usage period is quite large and will be smaller in the end of its usage. The advantage of this method is if the asset is damaged or stopped its use up, the amount of depreciation that has been done is big enough, so the losses suffered is not too big compared to the straight-line method.

Below is a comparison of the straight-line method of income statements and the method of declining balances 31 December. 
Table 3.

Straight-Line Method

\begin{tabular}{|c|c|c|c|c|}
\hline & 2014 & 2015 & 2016 & 2017 \\
\hline \multicolumn{5}{|l|}{ Incomes } \\
\hline Sales & $225,376,500$ & $324,231,485$ & $333,773,254$ & $352,254,789$ \\
\hline Service income & $161,438,750$ & $351,245,251$ & $385,125,148$ & $399,930,010$ \\
\hline total & $386,815,250$ & $675,476,736$ & $718,898,402$ & $752,184,799$ \\
\hline \multicolumn{5}{|l|}{ Cost of goods sold } \\
\hline Salary expense & $66,919,800$ & $140,215,487$ & $147,124,571$ & $150,124,584$ \\
\hline Raw Materials Expense & $200,254,476$ & $287,512,459$ & $299,014,571$ & $302,100,451$ \\
\hline Overhead Expense & $44,208,027$ & $66,976,163$ & $68,214,541$ & $70,014,451$ \\
\hline COGS & $311,382,303$ & $494,704,109$ & $514,353,683$ & $522,239,486$ \\
\hline Profit/loss & $75,432,947$ & $180,772,627$ & $204,544,719$ & $229,945,313$ \\
\hline \multicolumn{5}{|l|}{ Operation Expense } \\
\hline Salary Expnese & $36,928,000$ & $80,795,500$ & $88,985,250$ & $89,124,147$ \\
\hline Office expense & $37,552,550$ & $46,123,896$ & $49,862,282$ & $43,124,578$ \\
\hline Depreciatin expense & $12,626,667$ & $37,698,756$ & $37,836,047$ & $37,836,047$ \\
\hline Other expense & 167,000 & 300,000 & 256,000 & 302,145 \\
\hline Marketing expense & 985,000 & 736,800 & 698,700 & 520,012 \\
\hline Operation expense & $88,259,217$ & $165,654,952$ & $177,638,279$ & $170,906,929$ \\
\hline Profit/Loss & $(12,826,270)$ & $15,117,675$ & $26,906,440$ & $59,038,384$ \\
\hline \multicolumn{5}{|l|}{$\begin{array}{l}\text { Incone and other } \\
\text { expense }\end{array}$} \\
\hline Interset income & 39,767 & 142,397 & 340,200 & 430,200 \\
\hline Other expense & $(1,724,400)$ & $(4,367,021)$ & $(5,000,000)$ & $(3,570,014)$ \\
\hline Total & $(1,684,633)$ & $(4,224,624)$ & $(4,659,800)$ & $(3,139,814)$ \\
\hline Profit /loss & $(14,510,903)$ & $10,893,051$ & $22,246,640$ & $55,898,570$ \\
\hline
\end{tabular}

Table 4.

Comparison of Income Statement Per 31 December The Balance Method Double Down

\begin{tabular}{|l|c|c|c|c|}
\hline & \multicolumn{1}{|c|}{$\mathbf{2 0 1 4}$} & \multicolumn{1}{c|}{$\mathbf{2 0 1 5}$} & \multicolumn{1}{c|}{$\mathbf{2 0 1 6}$} & \multicolumn{1}{c|}{$\mathbf{2 0 1 7}$} \\
\hline Income & & & & \\
\hline Sales & $225,376,500$ & $324,231,485$ & $333,773,254$ & $352,254,789$ \\
\hline Service Income & $161,438,750$ & $351,245,251$ & $385,125,148$ & $399,930,010$ \\
\hline Total & $\mathbf{3 8 6 , 8 1 5 , 2 5 0}$ & $\mathbf{6 7 5 , 4 7 6 , 7 3 6}$ & $\mathbf{7 1 8 , 8 9 8 , 4 0 2}$ & $\mathbf{7 5 2 , 1 8 4 , 7 9 9}$ \\
\hline COGS & & & & \\
\hline Salary Expense & $66,919,800$ & $140,215,487$ & $147,124,571$ & $150,124,584$ \\
\hline
\end{tabular}

Rina Indrayani:

Analysis Use of Fixed Assets Depreciation Method on Company Profits 


\begin{tabular}{|c|c|c|c|c|}
\hline & 2014 & 2015 & 2016 & 2017 \\
\hline Raw Materials Expense & $200,254,476$ & $287,512,459$ & $299,014,571$ & $302,100,451$ \\
\hline Overhead expense & $44,208,027$ & $66,976,163$ & $68,214,541$ & $70,014,451$ \\
\hline COGS & $311,382,303$ & $494,704,109$ & $514,353,683$ & $522,239,486$ \\
\hline Gross Profit and Loss & $75,432,947$ & $180,772,627$ & $204,544,719$ & $229,945,313$ \\
\hline \multicolumn{5}{|l|}{ Operation Expense } \\
\hline Employee expense & $36,928,000$ & $80,795,500$ & $88,985,250$ & $89,124,147$ \\
\hline Office expense & $37,552,550$ & $46,123,896$ & $49,862,282$ & $43,124,578$ \\
\hline Depreciation expense & $25,253,333$ & $68,439,032$ & $50,055,615$ & $36,836,929$ \\
\hline Other Expense & 167,000 & 300,000 & 256,000 & 302,145 \\
\hline Marketing expense & 985,000 & 736,800 & 698,700 & 520,012 \\
\hline Opeartion Expense & $100,885,883$ & $196,395,228$ & $189,857,847$ & $169,907,811$ \\
\hline $\begin{array}{l}\text { INCOME OPERATING } \\
\text { LOSSES }\end{array}$ & $(25,452,936)$ & $(15,622,601)$ & $14,686,872$ & $60,037,502$ \\
\hline \multicolumn{5}{|l|}{$\begin{array}{l}\text { Income and other } \\
\text { expense }\end{array}$} \\
\hline Interest income & 39,767 & 142,397 & 340,200 & 430,200 \\
\hline Other expense & $(1,724,400)$ & $(4,367,021)$ & $(5,000,000)$ & $(3,570,014)$ \\
\hline Total & $(1,684,633)$ & $(4,224,624)$ & $(4,659,800)$ & $(3,139,814)$ \\
\hline Profits & $(27,137,569)$ & $(19,847,225)$ & $10,027,072$ & $56,897,688$ \\
\hline
\end{tabular}

Based on the above table it can be seen that at the beginning of earnings period according to the straight-line method is greater than double balance profit decreases, but in the next period the profit generated by double balance method is greater when compared to the straight-line method. One of the reasons for this difference is the recognition of the depreciation cost. For the straight-line method the cost of depreciation is likely to remain so that the effect on earnings is very small. As for the method of declining balance the cost of depreciation tends to decrease, so that the resulting profit increases. In the method of declining balance in the early days of its usage is quite large and will be smaller in the end of its use. The advantage of this method is if the asset is damaged or stopped before its expired, the amount of depreciation that has been done is large enough, so the losses suffered are not too large compared to the straight-line method.

From the above explanation can be seen that both methods have an influence on the value of profit to be achieved company. This happens because the value of depreciation by the straight-line method tends to be constant while the method of declining multiplier declines from year to year. In view of these conditions the company may choose one of the two most profitable methods in accordance with the company's plan of interest, since the cost of depreciation is a recognized cost but its expenditures never occur so that this cost is a source of funds for the company. Besides, the size of the depreciation expense has an effect on the company's profit. The greater the depreciation cost, the profit will be small and this has to do with the tax payment issue for the company. 


\section{CONCLUSION}

Based on the results of research conducted on the analysis of the effect of methods of depreciation of fixed assets to the company's income statement, then the conclusion are:

1. The implementation of accounting depreciation of fixed assets applied by the company so far has been good enough and has been in accordance with IFRS or generally accepted accounting principles.

2. By comparing the depreciation method used is the straight line method with the balance decrease in multiple, it turns out the accounting policy of depreciation of fixed assets applied by the company have an effect on the profit. Using the straight-line method will result in greater profits in the early years and the next year will be smaller, while the method of balance decreases in the opposite way, ie in the earliest years the resulting profit is less than the previous period.

\section{REFERENCES}

Baridwan, Zaki, (2014). Intermidiate accounting. Edisi ke 8, Yogyakarta : BPFE Yogyakarta.

Kasmir, (2013), Analisis laporan keuangan. Jakarta : Kencana Prenada Media Grup.

Ikatan Akuntansi Indonesia, (2009). Standar Akuntansi Keuangan. Jakarta : Salemba.

Kieso, Donald E, Jerry J. Weygandi dan Terry D Warfield. (2010). Acounting intermediate. Jakarta; Erlangga.

Gunadi, (2009). Akuntansi pajak sesuai dengan undang-undang pajak baru, Jakarta : Gramedia Widiasarana Indonesia.

Sekaran, (2006), Research methods for business, Edisi ke 4, Alih Bahasa Indonesia: Kwan Men Yon, Salemba Empat, Jakarta.

Skousen, K. F. dan Smith, J. M., (2012), Akuntansi intermediate jilid 1 dan 2 edisi ke-9, Erlangga Jakarta.

Sugiyono, (2012), Metode penelitian bisnis, Alfabeta, Bandung.

Rina Indrayani:

Analysis Use of Fixed Assets Depreciation Method on Company Profits 
The Accounting Journal of BINANIAGA Vol. 03, No. 01, June 2018 PISSN: $2527-4309$

EISSN: $2580-1481$

This page intentionally be emptied. 